summary of this research - van der Pligt insists on the rationality of those suspicious of nuclear reactors, which exemplify risks that are invisible, involuntary, uncontrolled, uncertain, delayed and irreversible - all traits that inspire dread. This technology, it seems, had characteristics especially likely to make people nervous.

Studies of risk perception, initiated in the 1970 s partly to understand why members of the public could be so irrational as to reject nuclear energy, have contributed a great deal to our understanding of public opinion and attitude formation. But van der Pligt's discerning if plodding use of this literature retains a flaw from the cognitive psychology that long dominated risk studies: a blindness to the formal organizations and political contexts shaping attitudes. Other than the frequent "credibility problems" of government agencies - meaning that they often lie to the public - van der Pligt ignores the ways that democratic procedures matter to people, that nuclear programmes come to be associated with political parties and agendas, that attitudes are ways to take sides in public debates.

Van der Pligt's claim that the public is rational combines easily with the evidence provided by Gallagher and Winkler. That many citizens of the advanced industrial world distrust nuclear fission follows from the pugnacious way in which their governments have imposed it on them, an anxiety only reinforced by the technology's riskiness, itself long denied by those in power. Although many scientists have played important roles as independent critics since the 1940 s, more have allowed themselves to become tools of their governments' enthusiastic promotional activities. The public might be willing to take more risks if they thought they could believe what the experts and officials were telling them about those risks. But so far, they have little reason to do so.

James M. Jasper is in the Department of Sociology, New York University, New York, New York 10003, USA.

\section{From scientist to courtier}

\section{William R. Shea}

Galileo, Courtier: The Practice of Science in the Culture of Absolutism. By Mario Biagioli. University of Chicago Press: 1993. Pp. 402. £23.95, \$29.95.

A VISITOR from a distant galaxy arriving on Earth as scientists are busy filling in applications for research grants would form a peculiar idea of this delicate operation. Most scientists go through the exercise under duress, some in sullen silence, others in a stream of expletives. $\mathrm{He}$ would hear much about the waste of precious time and the arbitrariness, if not lunacy, of questions about the goal of their research, the equipment, methodology and technical support needed, and, last but not least, clearance from their ethics committee. He would discover scientists vetting friends' proposals to see how they will go down with the adjudicatory committee, and rumours might reach him of scientists offering to say a word in high places. He could not fail to notice that the pecking order in some disciplines is determined by the size of one's grant. On return to his galaxy, we would not be surprised if the visitor wrote an essay on terrestrial science in which grantsmanship figured prominently.

What an extraterrestrial had to say about our system of supporting research would be of the highest interest. Might he say of contemporary scientists what Biagioli says of Galileo? "The place of gifts within the logic of patronage explains the role of spectacular scientific produc- tion in Galileo's career. Galileo needed to produce or discover things that could be used as gifts for his patrons." Are twentieth-century scientists tempted to do work that yields tangible results, however secondary, instead of tackling fundamental problems whose solution may bring no immediate relief to man's estate and so fail to qualify for the largesse of funding authorities? We cannot discount the pressures of contemporary patronage. On occasion, the research they want becomes the research we want simply because there is no other way of carrying on. The marvel is that so many scientists are willing to pass up the big bucks in the hope of a big breakthrough.

Every society has its own system of benevolent or despotic patronage. It needed someone as gifted and knowledgeable as Mario Biagioli to explore the relationships between science and government in seventeenth-century Italy. No historians of the period will leave this book without having learned something about the Tuscan court or the Roman famiglia (as the popes called their own entourage). But will they be greatly enlightened about Galilean science and the birth of the scientific revolution? My guess is that they will have learned as much about Galileo's mechanics as our extragalactic visitor would know about condensed matter after a few days observing physicists cobbling together a grant proposal.

In fact, and Biagioli makes no bones about this, Galileo became a courtier (in the sense of having a court appointment) only when he was named "Philosopher and Chief Mathematician of the Grand Duke of Tuscany" in 1610 . Galileo was then 46 years old and his best scientific work was behind him. Although his two main books, the Dialogue on the Two Chief World Systems: Ptolemaic and Copernican and the Two New Sciences were not published until 1632 and 1638, respectively, they were the fruits of his professorship at the University of Padua between 1592 and 1610. Galileo left the Venetian republic not to become a courtier in Florence but to have more time to arrange his material for publication. He wrote to the secretary of state of Tuscany on 7 May 1610: "If I could be repatriated, I would wish the Grand Duke to give me the leisure and the opportunity to draw my work to a conclusion without having to teach". Galileo got what he wanted: a professorship at the University of Pisa without obligation to give lectures or even reside in the city.

Biagioli recognizes that Galileo planned on enjoying the amenities of a research chair but argues that circumstances compelled him to change his role. The reader is invited to witness Galileo's "selffashioning" into a courtier and to realize

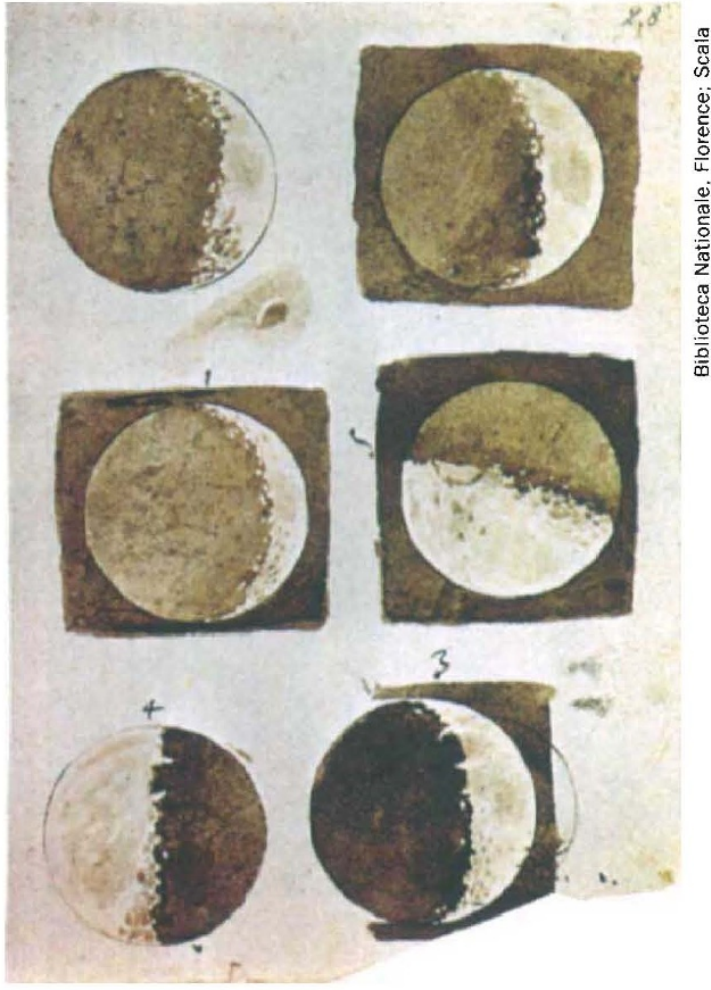

Galileo's sketches of the Moon pockmarked with mountains and craters, which were considered heretical for showing an imperfect heaven. 
that "usually Galileo was not attacked because he was a Copernican but because of his (and his discoveries') extreme visibility and his success in becoming the mathematician and philosopher of the Grand Duke". In 1611 Galileo was welcomed at the Collegio Romano, the Jesuit University in Rome, where his telescopic observations were publicly praised praise worth having, because the Jesuits, among whom were some of the best scientists in Europe, had made their own telescopes and confirmed Galileo's discoveries of craters on the Moon and satellites around Jupiter. We are now told, however, that Galileo's Roman Triumph "should be understood in terms of his connection to the Medici" and that he went to Rome as their "official envoy". The reason is that the government of Tuscany paid his travel expenses. On these grounds, shouldn't British scientists' lecture tours and attendance at meetings be "understood" in terms of the policy of the Royal Society?

Biagioli is more convincing when, in the footsteps of R. S. Westfall, he traces the relationship of Galileo with Prince Cesi, the founder of the Accademia dei Lincei, which Galileo joined in 1611, the year of his great success in Rome. As Galileo's patron, Cesi steered the Letters on the Sunspots (1613) and The Assayer (1623) through the shoals of Roman censorship and had them published at his own expense. Galileo hoped that he would also smooth, financially and otherwise, the path of the Dialogue on the Two Chief World Systems, but the Prince's death in 1630 deprived him of this influential friend and protector.

Biagioli's emphasis on patronage is also helpful in understanding the reaction of Pope Urban VIII to the publication of the Dialogue in 1632. The pope had treated Galileo with warmth and friendliness, and he expected to be repaid with courtesy and deference. The Roman censor had enjoined Galileo to mention the pope's view on the relativity of scientific theories and the impossibility of knowing with absolute certainty whether a given theory is more than a useful hypothesis. Galileo complied to the extent of stating this opinion (which he ascribes to "a most learned and eminent person") at the end of his book. Unfortunately, he puts it in the mouth of Simplicio, the Aristotelian pedant who cuts such a sorry figure throughout the entire Dialogue. Pope Urban VIII was personally affronted and bore Galileo a grudge to his dying day. Such bitterness might seem unbecoming for the Head of Christendom; Biagioli shows that it was comprehensible in a seventeenth-century patron.

William R. Shea is in the Philosophy Department, McGill University, 3690 Peel Street, Montreal, Quebec, Canada H3A 1 W9.
Relative values

\section{Arthurl. Miller}

The Private Lives of Albert Einstein. By Roger Highfield and Paul Carter. Faber and Faber: 1993. Pp. 355. £14.95.

LIFE can be complicated, especially in matters of the heart. So we ought not to be surprised that this was also true for Albert Einstein. Roger Highfield and Paul Carter have used Einstein's personal correspondence, some of it discovered as recently as 1986 , to produce a narrative that reveals him to have experienced angst and joys not uncommon to most mortals.

But would this book have the same

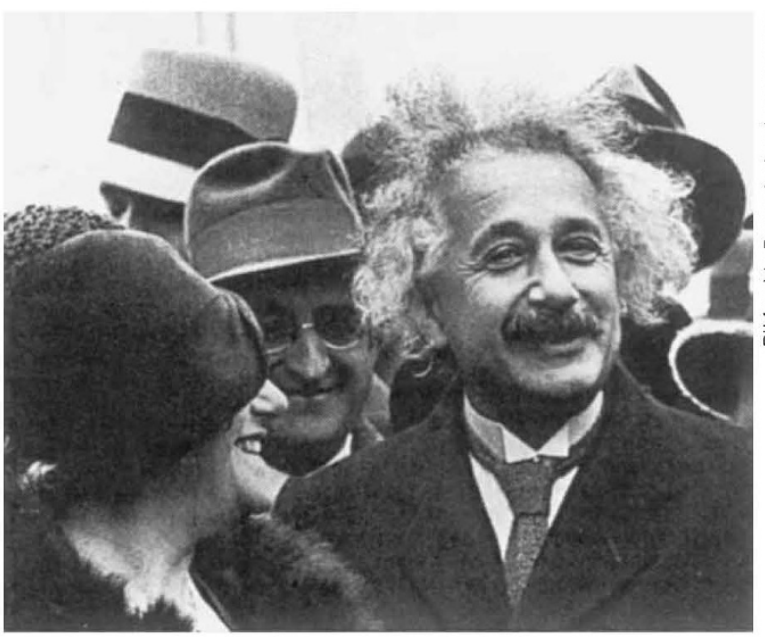

Einstein with his second wife and distant cousin Elsa.

interest if we removed the name Albert Einstein? Let's do that and see what remains. We have the story of a precollege student who falls madly in love, writes syrupy love letters to his beloved and courts her vigorously until she professes her love for him. Having achieved his desired end he beats a hasty retreat, preferring action at a distance. Finally the going gets too much and he ends the relationship.

Our 'hero' goes on to university where he falls in love (again) and a tumultuous love affair ensues, love letters and all. Being no Lord Byron, these letters are essentially the same as the previous ones. So is his preference for action at a distance once his girlfriend falls madly in love with him. He has doubts but doesn't want to lose her, preferring passionate reunions to a day-to-day relationship.

Both parents strongly oppose the liaison, his more than hers. He graduates from university, she does not. The plot thickens when the girlfriend becomes pregnant and, though he seems mildly enthusiastic about the baby, work comes first. They put the child up for adoption before he does the 'decent' thing and marries her. Their close relationship is renewed with her totally dependent on him but he buries himself even deeper in his work. Then another child arrives, she becomes jealous of his friends and of any extra-familial activities and now the couple who could not live apart discover they cannot live together. He becomes unexpectedly successful and is offered positions elsewhere and expects her to move with him along with their two children. He feels suffocated by the relationship, while she takes refuge in the children. Sounds familiar? Let's continue.

A distant cousin 'on the prowl' arranges a meeting and the married man indulges himself. A liaison follows, as do love letters of course. A major position opens in the cousin's home town, which he accepts; the wife refuses to $\approx$ go. After the divorce our by now fantastically successful figure marries the cousin. $\mathrm{He}$ becomes bored and is distracted by the attentions of other women. The middle-aged man embarks on affairs - some with love letters, of course. Meanwhile the children from the first marriage have nothing but scorn for the second wife, seeing in her the miseries of their mother, still in love with the image of the passionate young man from her vanished youth.

With Albert Einstein as the central figure, this scenario takes on added interest. Einstein did more than create scientific theories that changed our view of nature; with Sigmund Freud he created the twentieth century. What is so amazing is that Einstein's most creative years were the ones spent in the Swiss Federal Patent Office in Berne, 1902-09, where he worked full time in addition to publishing about 50 scientific papers. Among them are the special theory of relativity and the groundwork for the general theory. Consequently, our eyes widen when, in the midst of a love letter to Mileva Marić in 1901, his college sweetheart and then first wife, he mentions "our work on relative motion". Passages such as this have led to the suggestion that Mileva deserves some of the accolades for special relativity. The authors review conclusive evidence to the contrary.

Highfield and Carter have an agenda: to smash an icon. So, for example, they spend an entire chapter on the 16-year-old Einstein's relationship with his first girlfriend, accusing him of being hypocritical for rejecting her pleas to spend more time together and then citing hearsay evidence from years later that he bears the blame for her subsequently unhappy life. 